A. Shyshatskyi ${ }^{1}$, O. Cherniak ${ }^{2}$, A. Lyashenko ${ }^{3}$, S. Paniuk ${ }^{4}$, A. Doroshets ${ }^{4}$, V. Savenko ${ }^{4}$, V. Mazurenko ${ }^{4}$, S.Hryhorak $^{4}$

${ }^{1}$ Central Research Institute of Weapons and Military Equipment of Armed Forces of Ukraine, Kyiv

${ }^{2}$ Military unit A0515, Kyiv, Ukraine

${ }^{3}$ Military institute of telecommunications and information named after Heroes of Krut, Kyiv, Ukraine

${ }^{4}$ National Defence University of Ukraine named after Ivan Chernyakhovsky, Kyiv, Ukraine

\title{
DEVELOPMENT OF THEORETICAL PROVISIONS OF TRANSMISSION OF DISCRETE MESSAGES OF MILITARY RADIOCOMMUNICATION SYSTEMS
}

\begin{abstract}
Modern military radio systems operate in the complex conditions of the electronic environment, due to the limited frequency range, the influence of deliberate interference and signal fading. One of the ways to improve the effectiveness of military radio communication systems is to develop indicators (methods, techniques) for evaluating the effectiveness of military radio communication systems. The analysis found that known approaches to evaluating the performance of military radio communications systems are based on the use of bit error probability in a channel, which is a rather rough indicator of channel estimation. This necessitates the development of theoretical provisions for the transmission of discrete messages to military radio systems. In order to improve the known theoretical provisions for the transmission of discrete messages of military radio communication systems, the authors of the article developed indicators for assessing the quality of functioning of military radio communication systems that operate in complex conditions of electronic conditions. In the course of the study, the authors of the research substantiated two indicators of link quality in the fading channel: the probability of correctly receiving a message of finite duration and the likelihood of a link of finite duration without breaks. The first metric is the overall metric (communication) quality of the communication, and the second metric is the quality of the channel in the session of the final duration. During the research, the authors used the basic principles of communication theory, theories of insecurity, the theory of transmission of discrete messages, etc. The proposed results can be used to evaluate the status of radio channels when they are exposed to a variety of origins and signal fading. The practical significance of these results is that they can be used to upgrade existing radios or to develop new ones by developing appropriate software.
\end{abstract}

Keywords: discrete messages, radio communication, communication theory, signal fading, interference.

\section{Introduction}

Modern military radio systems operate in the complex conditions of the electronic environment, due to the limited frequency range, the influence of deliberate interference and signal fading. One of the ways to improve the effectiveness of military radio communication systems is to develop indicators (methods, techniques) for evaluating the effectiveness of military radio communication systems. This necessitates the development of theoretical provisions for the transmission of discrete messages to military radio systems.

In the general case, signal fading is present in the radio channels due to the multipath propagation of the electromagnetic wave $[1,2]$. As the range increases, their depth also increases. The channel becomes first Raysian, and on the border of direct visibility, it is Rayleigh [3]. It is noted that the robustness of the radio communication system for individual channel implementations may differ significantly from the average error probability, so it is averaged across all implementations.

This leads to a rather rough description of the physical channel $[4,5]$. In this case, the actual channel metrics are significantly different from the estimates.

All of this leads to the search for new approaches to the description of fading channels.

In view of the foregoing, the purpose of the article is to develop theoretical provisions for the transmission of discrete messages to military radio systems over signal fading channels.

\section{Presentation of the main material}

While transmitting discrete messages in a channel with constant parameters and white noise, the primary indicator of radio quality is the average probability of a $P_{\text {ber }}$ bit error. The second indicator is the probability of correct reception $P_{\text {rec }}$ of a message (code group) of $n$ characters. In a channel with constant parameters $P_{\text {rec }}$ in the absence of redundancy, it is calculated by the formula [1]

$$
P_{\text {rec }}=\left(1-P_{b e r}\right)^{n} \text {. }
$$

We have the other situation when the channel has a random fading signal at the input of the receiver (demodulator). In this case, the average fading probability of a $P_{\text {ber }}$ bit error, the probability of correctly receiving a $P_{\text {rec }}$ message, and the reliability of $H$. The indicator $\bar{P}_{\text {rec }}$ can be interpreted ambiguously.

At the link layer, character transfer protocols with punctuation are used to reduce the effect of fading on error grouping to ensure their correlation in the message (code group). The calculations show that the transmission speed is significantly reduced.

In addition, the correct reception of the message of a big payoff is not achieved, since the calculation uses the average for all implementations the probability of a $\bar{P}_{\text {ber }}$ bit error, which is usually $2-3$ orders of magnitude greater than the probability of a bit error in the channel without fading is $P_{\text {ber }}$.

The article [5] gives an example of calculating the probability of receiving a message correctly in 200 
characters and shows that the transmission rate in the channel decreases 7.5 times.

However, in the monograph [1], examples of calculations by the standard method are given. These calculations show that the code groups (messages) without interleaving when averaged over a onedimensional probabilistic model of the fading process have higher correctness of message reception than when using interleave and $P_{\text {ber }}$ indicator.

Thus, in these examples, it is shown [1] that in order to achieve the same probability of mistakenly receiving a 100-bit code combination, for example, in Rayleigh fading using the indicator $\bar{P}_{\text {ber }}$, the average transmitted signal power needs to be increased 550 times with respect to channel conditions without fading, but without the use of alternation, it is enough to increase only 50 times.

In the article [1], it was concluded: "... if the channels are compared with the probability of correctly receiving relatively long code combinations, the presence of slow fading does not impair the quality of the channel, as compared with the likelihood of receiving a single character correctly". Based on the above, we can conclude that there is ambiguity in the results of calculations when the difference is more than an order of magnitude. It should be noted that the length of the code group is determined by the number of characters, and does not indicate its duration and effect on the quality of reception of messages, for example, the length of the correlation interval.

However, the fading of the signal in the physical channel leads to errors in the reception of symbols at the channel level (in the discrete channel), which can be grouped within the code group (message). Known methods that are based on the models of Hilbert, ElliotHilbert, Fritschman and others are used for the statistical description of these groups [6-10].

Formalized error grouping models have nothing to do with signal fading in a physical channel. Parameters of the model of error grouping are usually adjusted by selection at a mode of test messages for a given time [6]. Thus, there is no relationship between the fading models in the physical channel and the error grouping patterns in the message in the discrete digital channel after detection.

In addition, the abovementioned works show that the averaged over the one-dimensional probability of fading, the bit error probability is a monotonic function of signal/noise ratio $\bar{h}^{2}=E / N_{0}$, where $E$ is the energy of the information symbol; $N_{0}$ is the one-way spectral noise density in the channel. And this view is used while calculating channel settings and radio quality in fading conditions.

However, in the article [1], it is shown that the local account of even a very small change in the signal level due to fading over the duration of the information symbol leads to a constant value $\bar{P}_{\text {ber }}$ after reaching a $\bar{h}^{2}$ certain value, so the $\bar{P}_{b e r}\left(\bar{h}^{2}\right)$ function ceases to be monotonic and reaches "saturation".
The specific value $\bar{P}_{\text {ber }}$ of "saturation" is determined by the type of function of the correlation coefficient of the fading process and the duration of the information symbol.

In these conditions, the graphs confirm that increasing the average level $\bar{h}^{2}$ or power of the signal does not reduce the probability of a $\bar{P}_{b e r}$ bit error.

As a result of these theoretical contradictions, the following interpretation of the mentioned "saturation" phenomenon is possible with regard to the rate of change of signal level.

The kind of $\bar{h}^{2}$ curve that corresponds to the rate of change of the signal level also changes, resulting in a change in the order of $\bar{P}_{b e r}\left(\bar{h}^{2}\right)$ magnitude, as if jumping to specific curves in the family of these curves $\bar{P}_{\text {ber }}\left(\bar{h}^{2}\right)$, even at constancy $\bar{h}^{2}$.

The abovementioned articles have adopted the characteristic of a communication channel at the physical layer - the reliability of communication, which shows the percentage of time when the signal level at the demodulator input is above the threshold and the communication quality is not worse than necessary. The reliability of communication is determined by the onedimensional probability of the fading process. At the channel level of message transmission, this characteristic is uninformative and does not reflect the actual duration of interruptions in the reception of messages caused, for example, disruption of synchronization, and the time spent on its recovery [8].

On the other hand, for example, in the article [7], it is shown that different types of formalization of calculations are possible while calculating lines of radio relay communication, which results in a significant difference in the obtained results.

Thus, in the presence of the signal fading in the physical channel classical theory of transmission of discrete messages has limited application, and the listed theoretical contradictions are caused by inconsistencies of the accepted one-dimensional probabilistic model.

First of all, the discrepancy of the accepted onedimensional probabilistic model is its onedimensionality. This model does not take into account the dynamics of the random fading process, its characteristics such as the autocorrelation function and the duration of the correlation interval, as well as other central and initial moments of the random process. When averaged over a one-dimensional probabilistic measure, the condition of so-called "local stationarity" is used, when the signal level (or transmission coefficient) remains unchanged for some time interval. At another interval, the channel is again considered constant, but maybe with different characteristics. The influence of channel behavior in intermediate states is not taken into account, it is believed that the signal level changes gradually.

Averaging over one-dimensional probability can be interpreted as follows. There are many channels 
(sessions) with constant but random gear ratios. In each communication session, such a constant channel with a random but fixed value of the transmission rate (signal level) is selected at random.

On many of these channels, we can see the average values of the transmission coefficient, the $\bar{h}^{2}$ signal/noise ratio, the probability of the $\bar{P}_{b e r}$ bit error, etc. At the same time, the relation to the actual operating conditions is the farthest, the dynamic characteristics of the fading process are not taken into account.

In order to exclude approaches to solving theoretical contradictions, it is proposed to introduce two indicators of link quality in a fading channel: the probability of receiving a $P_{\text {rec end }}^{*}$ correct finite duration message and the probability of a termination link without $P_{\text {without pre }}$ interruptions.

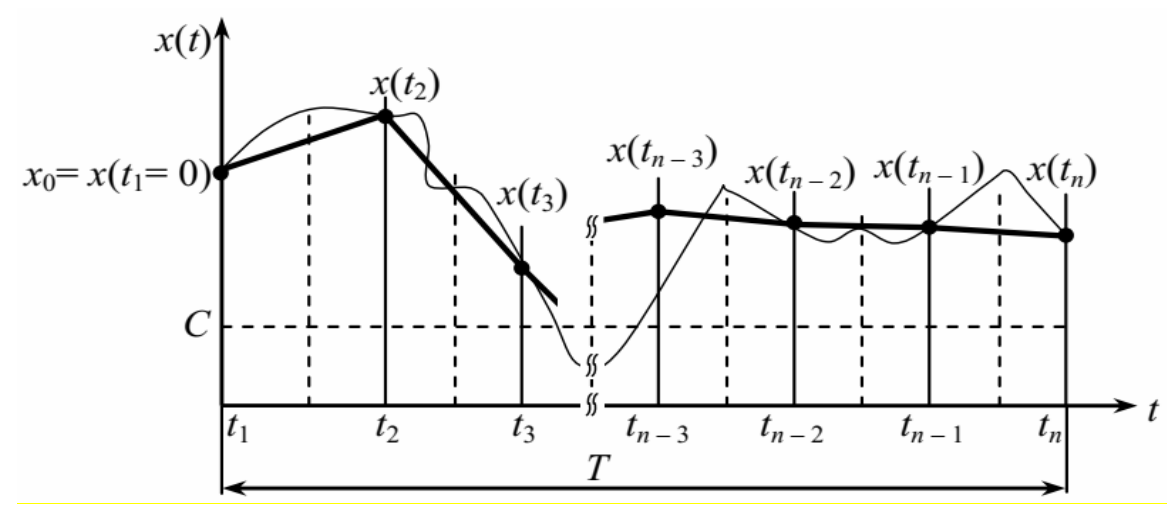

Fig. 1. Approximation of the continuous realization of a random process by a broken line with "vertices" in time intervals within the time interval $T$ is observed
The first metric is the overall metric quality of the communication, and the second metric is the quality of the channel in the session of the final duration.

The probability of $P_{\text {without pre }}$ non-interruption communication at a finite time interval $\mathrm{T}$ indicates the probability that during this time the signal level does not fall below the set threshold. This interval, including, can be the duration of the received message (code group).

The introduction of such an indicator requires the use of a probabilistic model of the random fading process in the form of a reduced multidimensional probabilistic measure $w(\vec{u})$.

For this purpose, it is proposed to approximate the continuous or even non-differentiated realization of a random process with a broken line with "vertices" at time intervals within the time interval $T$ (Fig. 1) [8].
In accordance with the abovementioned indications, the probability of correctly receiving a message with a duration of $T$ in the channel with a fading signal is determined by the expression

$$
P_{\text {rec end }}^{*} \geq P_{\text {rec end }} P_{\text {without_pre }}
$$

where $P_{\text {rec end }}$ is the probability of correctly receiving messages of finite duration without signal fading.

The probability of unbroken communication $P_{\text {without_pre }}$ is determined by the formula [8]

$$
P_{\text {without_pre }}=\iint_{\vec{u} t h r}^{\vec{\infty}} \ldots \int w(\vec{u}) d \vec{u} .
$$

In the formula (3), the following notation is introduced:

$\vec{u}$ is the value of the vector random value of the signal level at the intervals of the time interval $T$ (the number of sections determines the dimension of the vector $\vec{u}$ );

$\vec{u}_{t h r}$ is the vector of signal level thresholds.

From the general formula below, one can obtain multivariate Rayleigh random distribution laws:

$$
w_{n}\left(r_{1}, r_{2}, \ldots, r_{n}, ; \tau\right)=\prod_{i=1}^{n} r_{i} / \sigma^{2 n}\left(1-R_{0}^{2}\right)^{n-1} \times
$$

$$
\times \exp \left\{\frac{r_{1}^{2}+\left(1+R_{0}^{2}\right) \sum_{i=2}^{n-1} r_{i}^{2}+r_{n}^{2}}{2 \sigma^{2}\left(1-R_{0}^{2}\right)}\right\} \prod_{i=1}^{n-1} I_{0}\left[\frac{R_{0} r_{i} r_{i+1}}{\sigma^{2}\left(1-R_{0}^{2}\right)}\right],
$$

where $r_{n}$ is the value of a random variable, $R_{0}$ is the random process correlation function.

From the abovementioned, you can draw the following conclusions:

1. The smaller the ratio of the correlation interval to the interval of the communication session, the less the likelihood of communication without interruptions, which is not shown in the one-dimensional case (straight), since the calculations are performed on the average of the entire implementation (one-dimensional distribution functions), do not take into account dynamic characteristics (correlation interval, transmission time limit). This phenomenon shows that when the correlation interval ratio is relatively low, the average error probability does not fully characterize the quality of the reception.

2. As the correlation interval increases with the transmission of the time interval, the message graphs, that are constructed on multidimensional distribution functions, asymptotically seek a one-dimensional distribution function.

This shows the consistency of the proposed approach with respect to the existing approach of calculating the probability of receiving a message. 


\section{Conclusions}

The theory of transmitting discrete messages in a fading channel requires refinement. In order to describe the process of transmitting discrete messages in a radio channel under freezing conditions, the probability of correctly receiving messages in the absence and in the presence of organized interference is an important characteristic. The traditional link reliability setting is not identical to this probability. While determining, it requires a different approach, namely, introducing an additional characteristic of the radio channel in the presence of fading, such a characteristic may be the probability of uninterrupted communication while transmitting a discrete message of finite duration.
Using the suggested link quality metric on a fading channel allows you to:

- without losing the bandwidth of the channel to ensure with high accuracy, while maintaining the required quality of the channel in real-time;

- predict the probability of receiving the message correctly when using the necessary measures to set the modes of transmission of discrete messages.

The fading channel quality indicators proposed in the article are used to detect and disperse signals against the background of noise, to calculate the noise and communication reliability and to evaluate the propagation characteristics of radio waves.

Future research will focus on developing methods for improving the immunity of military radio systems.

\section{REFERENCES}

1. Shyshatskiy, A.V., Bashkirov, O.M. and Kostina, O.M (2015). "Development of integrated systems and data for Armed Forces", Arms and military equipment, No 1(5), pp. 35-40. available at: http://journals.uran.ua/index.php/24140651/issue/view/1\%285\%29\%202015 (last accessed January 25, 2020).

2. Korneyko, O. V., Kuvshinov, O. V. and Lezhniuk, O. P(2010). "The basics of the theory of telecomunication", Kyiv, 786 p.

3. Varakin, L.E.(1970). "Theory of complex signals". Mocsow . Radio, 304 p.

4. Sklyar, B (2003). "Digital communication. Theoretical foundations and practical application", Moscow, Williams.

5. Zhuk, O.G., Shyshatskiy, A.V., Zhuk, P.V. and Zhyvotovskyi, R.M (2017). "Methodological substances of management of the radio-resource managing systems of military radio communication", Information Processing Systems, Vol. 5(151), pp. 16-25. https://doi.org/10.30748/soi.2017.151.02 (last accessed January 25, 2020).

6. Shyshatskyi, A. V., Olshanskyi, V. V. and Zhyvotovskyi, R. M(2016). "Algorithm of the choosing working frequencies for facilities of military radio communication in the conditions of intentional interference". Systems of armament and military equipment. No. 2. - P. 62-66. available at: http://www.hups.mil.gov.ua/periodic-app/article/16881.

7. Romanenko, I. O., Shyshatskyi, A.V., Zhyvotovskyi, R. M. and Petruk, S.M (2017). "The concept of the organization of interaction of elements of military radio communication systems". Science and Technology of the Air Force of the Armed Forces of Ukraine. No 1. pp. 97-100.

8. Sova O.Ya., Romanuk, V.A. Zuk, P.V. and Umanec, Ya. L(2012). "Synthesis methodology of smart nodes management systems of perspective mobile radio networks with dynamic topology". Collection of scientific works of HUPS. No 3. pp. $51-60$.

9. Sova, O. Ya., Minochkin, D.A., Romanyuk, V.A. and Zhuk, P.V(2015). "Model of organization of information resources of intelligent management systems of nodes of mobile radio networks of the class MANET". Science and Technology of the Air Force of the Armed Forces of Ukraine. No. 2(19). pp. 51-57.

10. Golubtsov, S. G. and Leonovich G.A (2009). "Methodology for assessing the effectiveness of the functioning of the field backbone communication network of an association by a comprehensive accessibility indicator". Science and military security. No. 3. pp. 23-29.

Надійшла (received) 08.01.2020

Прийнята до друку (accepted for publication) 25.03.2020

\section{Розвиток теоретичних положень передачі дискретних повідомлень систем військового радіозв'язку}

А. В. Шишацький, О. Р. Черняк, Г. Т. Ляшенко, С. А. Панюк, А. В. Дорошець,

В. В. Савенко, В. М. Мазуренко, С. В. Григорак

Анотація. Сучасні системи військового радіозв'язку функціонують в складних умовах радіоелектронної обстановки, що обумовлені обмеженістю частотного діапазону, впливом навмисних завад та завмирань сигналу. Одним 3 напрямків підвищення ефективності систем військового радіозв'язку є розвиток показників (методів, методик) оцінювання ефективності систем військового радіозв'язку. Під час проведеного аналізу встановлено, що відомі підходи 3 оцінювання ефективності систем військового радіозв'язку засновані на використанні ймовірності бітової помилки в каналі, що є досить грубим показником оцінки каналів. Зазначене обумовлює необхідність проведення розвитку теоретичних положень передачі дискретних повідомлень систем військового радіозв'язку. 3 метою удосконалення відомих теоретичних положень передачі дискретних повідомлень систем військового радіозв'язку авторами статті проведено розробку показників оцінки якості функціонування систем військового радіозв'язку, що функціонують в складних умовах радіоелектронної обстановки. В ході проведення дослідження авторами дослідження було обгрунтовано два показника якості зв'язку в каналі із завмираннями: ймовірність правильного прийому повідомлення кінцевої тривалості та ймовірність зв'язку кінцевої тривалості без обривів. Перший показник є загальним показником якості (зв'язку) передачі інформації, а другий - показником якості каналу на сеансі зв'язку кінцевої тривалості. В ході проведеного дослідження авторами були використані основні положення теорії зв'язку, теорії завадозахищеності, теорії передачі дискретних повідомлень та інш. Запропоновані результати можуть бути використані під час оцінюванні стану каналів радіозв'язку при впливі завад різноманітного походження та завмирань сигналу. Практична значимість зазначених результатів полягає в тому, що вони можуть бути використанні при модернізації існуючих засобів радіозв'язку або під час розробки нових засобів шляхом розробки відповідного програмного забезпечення.

Ключ ов і слов а: дискретні повідомлення, система радіозв'язку, теорія зв'язку, завмирання сигналу, завади. 